\title{
Thermo-Chemical Conversion of Jatropha Deoiled Cake: Pyrolysis vs. Gasification
}

\author{
Rajeev Sharma and Pratik N. Sheth
}

\begin{abstract}
Pyrolysis and gasification of biomass is considered to be the promising alternative solutions for the increase of energy demand and environmental awareness. Pyroysis process produces a variety of chemicals by limited degradation and gasification process leads to complete breakdown of the biomass into permanent gases. By gasification, solid biomass is converted into a combustible gas mixture normally called "Producer Gas" consisting primarily of hydrogen and carbon monoxide, with lesser amounts of carbon dioxide, water, methane, higher hydrocarbons, nitrogen and particulates. Whereas the pyrolysis process produces a mainly three types of products: solid (charcoal), liquid (tar and other organics) and gaseous products. In the present study, Jatropha de-oiled cake is taken as a biomass. The pyrolysis and gasification experiments are carried out for comparing the results. The biomass is pyrolyzed in a fixed bed reactor in a Nitrogen environment as well used to produce the producer gas in a fixed bed downdraft biomass gasifier.
\end{abstract}

Index Terms-Biomass, gasification, jatropha de-oiled cake, pyrolysis.

\section{INTRODUCTION}

Highlight The demand for energy is increasing at an exponential rate due to the rapid growth of world population. World relies heavily on petroleum products to meet industrial and domestic needs. Prior to industrial revolution the energy requirements were achieved from the natural resources and forest produce. With the discovery of crude oil in 1860, the world has shifted to unsustainable energy consumption pattern based on petroleum based fuels as energy. This, combined with the widespread depletion of fossil fuels and gradually emerging consciousness about environmental degradation, suggests that the energy supply in the future has to come from renewable sources of energy [1]. Extensive research is going on to reduce dependence on the conventional fossil fuels and to replace sizeable portion of conventional fuels with alternative fuels. Not only the depletion of the fossil fuels but also the $\mathrm{CO}_{2}$ emissions from the use of fossil fuels that provide about $85 \%$ of the total world demand for primary energy, cause the observed increase of the $\mathrm{CO}_{2}$ concentration in the atmosphere. Which will increase the warming at a rate unprecedented in human history due to $\mathrm{CO}_{2}$ being added to the atmosphere by unsustainable growth. The use of biomass fuels in a closed carbon cycle, as a substitute for fossil fuels, is one of the most promising ways for halting the increase of the $\mathrm{CO}_{2}$

Manuscript received October 28, 2014; revised January 16, 2015.

The authors are with the Birla Institute of Technology and Science, Pilani, India (e-mail: pratik@pilani.bits-pilani.ac.in). concentration. Biomass fuels make no net contribution to atmospheric $\mathrm{CO}_{2}$ if used sustainably to allow re-growth. Biomass is an important source of energy and the most important fuel worldwide after coal, oil and natural gas. Biomass includes a wide range of fuels such as wood; agricultural crops especially cultivated for energetic purpose, forest and agricultural residues and are closely related to other fuels such as waste from both industries and households, and peat. Most biomass is living or dead plants, which use the process of photosynthesis to create stored chemical energy. Photosynthesis involves the use of energy in sunlight to convert carbon dioxide and water to carbohydrates, which are a source of chemical energy. The supply of energy from biomass plays an increasing role in the debate on renewable energies [2]. Biomass is composed of organic carbonaceous materials such as woody or lignocellulosic materials, various types of herbage, especially grasses and legumes, and crop residues. The energetic and industrial usage of biomass is becoming more and more technologically and economically attractive. The use of biomass offers the advantage of benefits as it is available in every country in various forms and thus assures supply of raw material to the energy system. Maintaining biomass as a significant contributor to the national energy supply is, for many countries, the best way of ensuring greater autonomy and a cheap energy for the industry [3]. It will also lead to socio-economic benefits including the creation of new employment opportunities in rural districts. The utilization of biomass for energy is also an alternative for decreasing current environmental problems such as $\mathrm{CO}_{2}$ increase in the atmosphere caused by the use of fossil fuels. Furthermore, bio-fuels contain minimal sulphur and avoid the release of $\mathrm{SO}_{2}$. It is more efficient to use lad to grow biomass for energy, offsetting fossil fuel use, than to simply sequester $\mathrm{CO}_{2}$ in forests. Biomass can be converted to various forms of energy by numerous processes, depending upon the raw material characteristics and the type of energy desired. Biomass is the most important renewable energy source in the world and its importance will increase as national energy policies and strategies focus more heavily on renewable sources and conservation. Biomass power plants have advantages over fossil-fuel plants, because their pollution emissions are less. Biomass can be used directly (e.g. burning wood for heating and cooking) or indirectly by converting it into a liquid or gaseous fuel (e.g. alcohol from sugar crops or biogas from animal waste). The net energy available from biomass when it is combusted ranges from about $8 \mathrm{MJ} / \mathrm{kg}$ for green wood, to $20 \mathrm{MJ} / \mathrm{kg}$ for dry plant matter, to $55 \mathrm{MJ} / \mathrm{kg}$ for methane, as compared with about 27 $\mathrm{MJ} / \mathrm{kg}$ for coal [4]. Biomass does not add carbon dioxide to the atmosphere as it absorbs the same amount of carbon in 
growing as it releases when consumed as a fuel. Conversion of biomass to energy is undertaken using two main process technologies: thermo-chemical and biochemical/ biological. Pyrolysis and gasification are the primary thermo-chemical conversion methods to convert biomass into valuable products namely; solid products (char and charcoal), liquid products (wood tar, tar, oil, and pyrolytic oil in case of pyrolysis) and gas products (producer gas in case of gasificationwood gas and pyrolytic gas) [5]. The liquid product obtained from pyrolysis is known as bio-oil or pyrolytic oil. Biochemical treatments proceed at mild operating conditions. However, slow productivity, requirement of pre-treatment to biomass and process wastes poses a problem for implementing it on a large scale. Bio-oil is a viscous, corrosive, and unstable mixture of a large number of oxygenated molecules, depending on the pyrolysis process and biomass feedstock. Due to the high oxygen content, the heating value is less than half that of petroleum liquid [6]. Bio-oil needs to be upgraded before use as liquid fuel. Various methods available include solvent fractionation, hydro-processing, and catalytic cracking [7].

\section{PYROLYSIS}

Pyrolysis is a thermal decomposition process that takes place in the absence of oxygen, which converts biomass into solid (charcoal), liquid (tar and other organics, such as acetic acid, acetone and methanol) and gaseous products $\left(\mathrm{H}_{2}, \mathrm{CO}_{2}\right.$, $\mathrm{CO})$ at elevated temperatures [8], [9]. In general, thermo-chemical and bio-chemical treatments are successfully employed to produce the bio-fuel from biomass [10], [11]. Based on the reaction temperature and residence time, pyrolysis process can be divided into conventional pyrolysis, fast pyrolysis and flash pyrolysis. The range of the main operating parameters for pyrolysis processes are given in Table I. Biomass is mainly composed of three constituents which are hemicelluloses, cellulose, and lignin. There are minor amounts of extractives also present. Each component of biomass pyrolyzes at different rates and by different mechanisms and pathways. It is believed that as the reaction progresses, the carbon becomes less reactive and forms stable chemical structures, and consequently the activation energy increases as the conversion level of biomass increases. Cellulose and hemicellulose decomposes over a very narrow temperature range as compared to lignin. The rate and extent of degradation of each of these components depends on the process parameters of reactor type, temperature, and particle size heating rates and pressure [12]. Thermal degradation properties of hemicelluloses, cellulose, and lignin can be summarized as follows: Thermal degradation of hemicelluloses $>$ of cellulose $>$ of lignin. The hemicelluloses break down first, at temperatures of 470 to $530 \mathrm{~K}$, and cellulose follows in the temperature range 510 to $620 \mathrm{~K}$, with lignin being the last component to pyrolyze at temperatures of 550 to $770 \mathrm{~K}$ [3].

\section{GASIFICATION}

Gasification of biomass is one of the majorly used processes to increase the efficiency of energy harnessing from biomass. Gasification is a process that takes carbonaceous materials as its feed, such as coal, petroleum, or biomass, and converts into carbon monoxide and hydrogen. The raw material reacts with a controlled amount of oxygen and/or steam at high temperatures. It is also a very efficient method for extracting energy from many different types of organic materials, and also has applications as a clean waste disposal technique. Moreover the usage of producer gas is potentially more efficient than direct combustion of the original fuel because it can be combusted at higher temperatures. The typical composition of hydrogen in producer gas varies from $5-25 \%$ depending upon moisture content of the fuel. After separation and purification, it can be utilized in fuel cell and biomass gasification process can be considered as a one of the prominent process for bio-hydrogen production. There are mainly two techniques available for gasification of biomass, viz., fixed bed mode and fluidized bed mode [11]. The three main configurations of fixed bed gasifiers include updraft, downdraft, and crossdraft mode of operations. In the updraft gasifiers, biomass moves down vertically and comes in contact with an upward moving product gas stream counter-currently. The updraft gasifier is easy to build and operate but product gas is very dirty with high amount of tar. It also has a high thermal efficiency as gases from the combustion zone passes upwards through incoming fuel, which preheat it [13]. In the downdraft gasifier biomass moves slowly downwards and air is introduced cocurrently and reacts at a throat that supports the gasifying biomass. They are cheap and easy to make. A relatively clean gas is produced with low tar and usually with high carbon conversion. In the cross draft gasifier, air is introduced on one side of the gasifier and the gas outlet is on the opposite side. Normally an air inlet nozzle is extended to the center of the combustion zone. The main advantages of the crossdraft gasifiers are: a. its rapid response to change in load, b. its simple construction and c. its lightweight. Out of different configuration of reactors for biomass gasification, a survey of gasifier manufacturers have reported that $75 \%$ of gasifiers offered commercially were downdraft, $20 \%$ were fluid beds [including circulation fluid beds], $2.5 \%$ were updraft, and $2.5 \%$ were of other types [14].

\section{ENXPERIMENTAL STUDIES}

The objectives of the proposed study is to compare the pyrolysis and gasification for a particular biomass i.e. Jatropha de-oiled cake. The pyrolysis study is carried out using fixed bed reactor and product yield is determined.

\section{A. Experimental Set-up}

Pyrolysis reactor is of fixed bed type and made of stainless steel and of cylindrical shape. The cylindrical reactor is having a diameter of $15.5 \mathrm{~cm}$ and height of $30 \mathrm{~cm}$, which is placed in an electrical furnace. The heating electrical furnace is connected to the temperature controller unit which governs the inside temperature of the reactor and also the heating rate. To create the inert environment, nitrogen gas is passed through reactor continuously. The sample gets pyrolysed and volatiles released along with inert nitrogen exits from the top 
of the reactor and are passed through a two stage condenser followed by an ice trap. The schematic drawing of the experimental set up is shown in Fig. 1. Further details are reported in our earlier publication [15] .

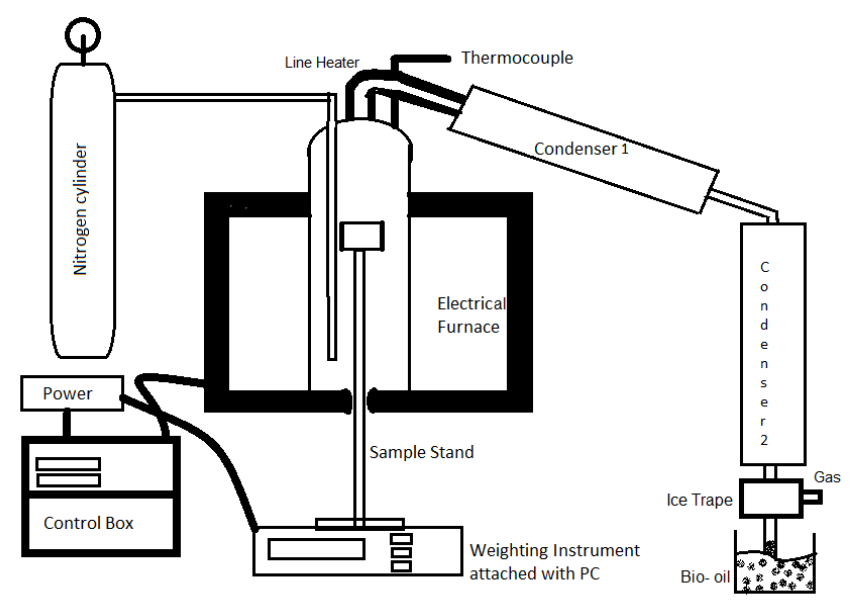

Fig. 1. Experimental set-up diagram.

\section{B. Biomass}

Jatropha Curcas has been identified as the most suitable energy crop for the production of bio diesel. It is a tropical plant that can be grown in low to high rain fall areas. It can be used to reclaim land, as a hedge and/or as a commercial crop. It is one of the renewable resources, not only as bio-energy, but also for medical, food, and non-food application. Jatropha is a multipurpose species with many attributes and considerable potential. As biomass, Jatropha is attracting great attention over the world as a source of renewable energy as well as an alternative to fossil fuels. The Jatropha plant is currently receiving a lot of attention as an energy plant [16].

The seed material comprises of $41 \%$ shell and $59 \%$ kernel. The kernel consists of $40-50 \%$ of oil [17]. Biodiesel production from Jatropha seeds generate large amount of residual deoiled seed cake. Although the oil is an excellent biodiesel feedstock, potential utilization or safe disposal of huge amounts of seed cake by-product needs to be addressed. The average chemical composition of deoiled seed cake is $60 \%$ protein, $0.6 \%$ fat, $9 \%$ ash, $4 \%$ fibre and $26 \%$ carbohydrates [18]. Jatropha curcas seed cake cannot be used as cattle feed, unlike other oil seeds mainly due to the presence of toxic phorbol esters in it. Phorbol esters have been identified as main toxicants in cake which could not be destroyed even by heating at $160{ }^{\circ} \mathrm{C}$ for $30 \mathrm{~min}$ [19]. De-oiled cake, a solid residue that was discarded after extraction of oil seeds, contains lignin and cellulose in varying ratios. Moreover due to increasing demand of biodiesel, lots of oil cakes have increased tremendously and about 2 tonnes of oil cake is dumped as a waste for every tonne of biodiesel production [20]. Large amount of de-oiled cake is generated as by-product during production of biodiesel from its seeds. This de-oiled cake is not utilised in spite of its energy value. In the present study, the Jatropha de-oiled cake is used for pyrolysis experimental study which is purchased from Gujarat, India based bio-products supplier.

Approximately $100 \mathrm{gm}$ of biomass sample having particle size of $0.177 \mathrm{~mm}>D_{\mathrm{p}}>0.210 \mathrm{~mm}$ is used in the present study.
The ultimate analysis of Jatropha de-oiled cake is carried out at Sigma Test and Research Centre, New Delhi, India and shown in Table I. The gross energy value is found to be 17.7 $\mathrm{MJ} / \mathrm{kg}$ using digital bomb calorimeter supplied by Popular Science Apparatus Workshops Pvt. Ltd.

TABLE I: UltimATE ANALYSIS OF JATROPHA DE-OILED CAKE

\begin{tabular}{|l|l|}
\hline Property & \\
\hline $\mathrm{C}(\%$ by mass $)$ & 53.39 \\
\hline $\mathrm{H}(\%$ by mass $)$ & 6.81 \\
\hline $\mathrm{O}(\%$ by mass $)$ & 29.27 \\
\hline $\mathrm{N}(\%$ by mass $)$ & 0.45 \\
\hline $\mathrm{S}(\%$ by mass $)$ & 0.12 \\
\hline $\mathrm{H} / \mathrm{C}$ Ratio & 1.53 \\
\hline Empirical Formula & $\mathrm{CH}_{1.53} \mathrm{O}_{0.4} \mathrm{~N}_{0.007} \mathrm{~S}_{0.0008}$ \\
\hline
\end{tabular}

\section{ExperimentalMethodology}

In the present study, the pyrolysis of Jatropha de-oiled cake is carried out at temperatures of $350,400,450,500,550$, $600,650,700$, and $750^{\circ} \mathrm{C}$ in a fixed bed batch reactor. Fixed-bed reactor having an internal volume of $22630 \mathrm{~cm}^{3}$ $(15.5 \mathrm{~cm}$ ID) which is heated externally by an electrical furnace and the temperature is measured by a thermocouple inside the reactor. Experimental runs are carried out under sweeping gas (nitrogen with a flow rate of 2 LPM) and solid, gas and liquid product yields are calculated. A fixed quantity of Jatropha de-oiled cake is placed on the sample holder and nitrogen gas is purged for $10 \mathrm{~min}$ at a flow rate of $2 \mathrm{~L} / \mathrm{min}$ to create an inert atmosphere. After that heating is started and the reactor temperature is increased from room temperature to the desired pyrolysis temperature. During the heating, volatiles are released and exit from the reactor and goes into the condenser. The pipeline carrying the volatiles from reactor to condenser is also maintained at a temperature of $250^{\circ} \mathrm{C}$ to avoid any condensation of volatiles before condenser. The volatiles are condensed to liquid products known as bio-oil. Table II shows the operating conditions of the various experimental runs performed in the present study.

TABLE II: DETAILS OF EXPERIMENTAL RUNS

\begin{tabular}{|l|l|l|l|}
\hline \multirow{2}{*}{$\begin{array}{l}\text { Experimental } \\
\text { Run No. }\end{array}$} & \multirow{2}{*}{$\begin{array}{l}\text { Biomass } \\
\text { Weight }(\mathbf{g m})\end{array}$} & Intial & Femperature $\left({ }^{\circ} \mathbf{C}\right)$ \\
\cline { 3 - 4 } & 91.6 & 28 & 350 \\
\hline Run 1 & 120.1 & 28 & 400 \\
\hline Run 2 & 123.9 & 28 & 450 \\
\hline Run 3 & 118.7 & 28 & 500 \\
\hline Run 4 & 128.2 & 28 & 550 \\
\hline Run 5 & 113.4 & 28 & 600 \\
\hline Run 6 & 119.6 & 28 & 650 \\
\hline Run 7 & 125.7 & 28 & 700 \\
\hline Run 8 & 119.5 & 28 & 750 \\
\hline Run 9 & & & \\
\hline
\end{tabular}

The gasification experimental details and methods are reported in our earlier publication [10], [11].

\section{RESUlTS AND DisCUSSION}

\section{A. Effect of Temperature on Yield of Products}

Fig. 2 shows the product yield distribution for the pyrolysis of Jatropha de-oiled cake carried out at different temperatures. The liquid product obtained has a reddish-brown color with an irritant odour. The liquid yield is 
$18 \%, 25 \%, 29 \%$ at pyrolysis temperatures 350, 400 and $450{ }^{\circ} \mathrm{C}$. The maximum liquid yield is $31.2 \%$ at $500{ }^{\circ} \mathrm{C}$, which further decreases with increase in temperature. The char yield gradually decreases from $48.25 \%$ to $31.8 \%$ with increase in temperature. The decrease in char yield with increasing temperature could be either due to greater primary decomposition or de-polymerization of de-oiled cake to primary volatiles at higher temperatures or may be due to secondary decomposition of the char residue [21]. The gas yield initially shows a downfall and then increases with an increase in temperature. This may be due to the secondary cracking of the pyrolysis vapours or the formation of some non-condensable gaseous products during secondary decomposition of the char at higher temperatures. The yield of products is also shown in Fig. 2.



Fig. 2. Product yield distribution of pyrolysis of jatropha de-oiled cake.

The details of the gasification experimental studies are reported in Table III.

TABLE III: DETAILS OF GASIFICATION EXPERIMENTS

\begin{tabular}{lllll}
\hline $\begin{array}{l}\text { Air Flow } \\
\text { rate } \\
(\mathrm{Nm} / \mathrm{hr})\end{array}$ & $\begin{array}{l}\text { Biomass } \\
\text { Consumption } \\
\text { rate }(\mathrm{kg} / \mathrm{hr})\end{array}$ & $\begin{array}{l}\text { Equivalence } \\
\text { ratio }\end{array}$ & $\begin{array}{l}\text { Producer } \\
\text { Flow } \\
\left(\mathrm{Nm}^{3} / \mathrm{hr}\right)\end{array}$ & $\begin{array}{l}\text { gas } \\
\text { rate }\end{array}$ \\
\hline 1.851 & 1.9 & 0.1866 & 1.924 & \\
\hline
\end{tabular}

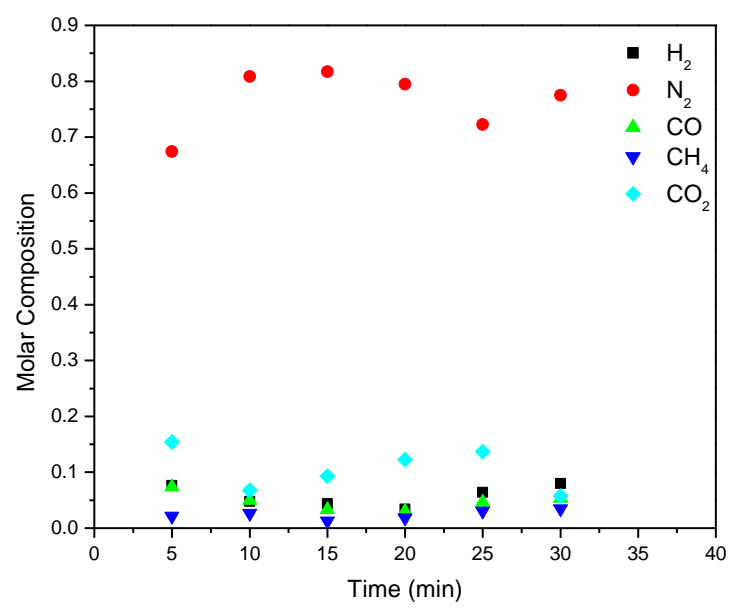

Fig. 3. Variation of molar composition with time.

Fig. 3 shows the variation of producer gas composition with time. The molar concentration of methane remains very less throughout the experimental run. The composition of carbon monoxide, carbon dioxide and hydrogen is varying continuously. The molar concentration of carbon dioxide is highest at the start of the experiment as the temperature of the reduction zone is very less initially. As time passes, the concentration of carbon monoxide and hydrogen decreases intitally and increases later once steady temperature zones are established. The molar content of nitrogen remains same as it is inert. After 15 minutes of operation, the molar concentraton of nitrogen remains constant.

Based on the average molar composition, producer gas flow rate is calculated based on Nitrogen balance. The calculated values of calorific value of the producer gas is 3.09 $\mathrm{MJ} / \mathrm{Nm}^{3}$.

\section{CONCLUSIONS}

From the present study, it can be concluded that the Jatropha residue cake can be successfully used to generate producer gas and also for the bio-oil production. In this study pyrolysis of Jaropha de-oiled cake in a fixed bed reactor is carried out for a temperature range of $350^{\circ} \mathrm{C}$ to $750^{\circ} \mathrm{C}$. The gases emitted from the pyrolyser are condensed to bio-oil. The yield of bio-oil initially increased and then decreased, a continuous fall is seen in the char yield whereas the gas yield decreased for the initial runs and then continuously increased with increase in temperature. This indicates that temperature has significant effect on pyrolysis yields and conversion efficiencies. The maximum yield of oil of $31.17 \%$ (by wt.) is obtained at $500^{\circ} \mathrm{C}$. The conversion efficiency in pyrolysis is comparable with the cold gas efficiency of the gasification experimental run.

\section{REFERENCES}

[1] A. Demirbas, "Gaseous products from biomass by pyrolysis and gasification: effects of catalyst on hydrogen yield," Energy Conversion and Management, vol. 43, pp. 897-909, 2002

[2] M. K. Bahng, C. Mukarakate, D. J. Robichaud, and M. R. Nimlos, "Current technologies for analysis of biomass thermochemical processing: A review," Analytica Chimica Acta, vol. 651, pp. 117-138, 2009.

[3] B. V. Babu, "Biomass pyrolysis: a state-of-the-art review," Biofuels, Bioproducts and Biorefining, vol. 2, pp. 393-414, 2008.

[4] A. Demirbas, "Biomass resource facilities and biomass conversion processing for fuels and chemicals," Energy Conversion and Management, vol. 42, pp. 1357-1378, 2001

[5] N. K. Nayan, S. Kumar, and R. K. Singh, "Production of the liquid fue by thermal pyrolysis of neem seed," Fuel, vol. 103, pp. 437-43, 2013

[6] A. Demirbas, "Competitive liquid biofuels from biomass," Applied Energy, vol. 88, pp. 17-28, 2011.

[7] D. Mohan, C. U. Pittman, and P. H. Steele, "Pyrolysis of wood/biomass for bio-oil: A critical review," Energy \& Fuels, vol. 20, pp. 848-89, 2006.

[8] L. Zhang, C. Xu, and P. Champagne, "Overview of recent advances in thermo-chemical conversion of biomass," Energy Conversion and Management, vol. 51, pp. 969-982, 2010.

[9] K. Murata, P. Somwongsa, S. Larpkiattaworn, Y. Liu, M. Inaba, and I. Takahara, "Analyses of liquid products from catalytic pyrolysis of jatropha seed cakes," Energy \& Fuels, vol. 25, pp. 5429-5437, 2011.

[10] P. N. Sheth and B. V. Babu, "Experimental studies on producer gas generation from wood waste in a downdraft biomass gasifier," Bioresource Technology, vol. 100, pp. 3127-3133, 2009.

[11] P. N. Sheth and B. V. Babu, "Production of hydrogen energy through biomass (waste wood) gasification," International Journal of Hydrogen Energy, vol. 35, pp. 10803-10810, 2010.

[12] A. V. Bridgwater, D. Meier, and D. Radlein, "An overview of fast pyrolysis of biomass," Organic Geochemistry, vol. 30, pp. 1479-1493, 1999.

[13] A. V. Bridgwater, "The technical and economic feasibility of biomass gasification for power generation," Fuel, vol. 74, pp. 631-653, 1995

[14] A. V. Bridgwater, "Thermal conversion of biomass and waste: The status," 2002, pp. 1-25.

[15] R. Sharma and P. N. Sheth, "Experimental investigations of thermal decomposition of jatropha residue cake," presented at 66th Annual 
Session of Indian Institute of Chemical Engineers, Institute of Chemical Technology, Mumbai, 2013.

[16] H. P. S. A. Khalil, N. A. S. Aprilia, A. H. Bhat, M. Jawaid, M. T Paridah, and D. A. Rudi, "Jatropha biomass as renewable materials for biocomposites and its applications," Renewable and Sustainable Energy Reviews, vol. 22, pp. 667-685, 2013.

[17] R. N. Singh, D. K. Vyas, N. S. L. Srivastava, and M. Narra, "SPRERI experience on holistic approach to utilize all parts of Jatropha curcas fruit for energy," Renewable Energy, vol. 33, pp. 1868-73, 2008.

[18] K. D. Rakshit, J. Darukeshwara, K. Rathina Raj, K. Narasimhamurthy, P. Saibaba, and S. Bhagya, "Toxicity studies of detoxified Jatropha meal (Jatropha curcas) in rats," Food and Chemical Toxicology, vol. 46, pp. 3621-5, 2008.

[19] H. P. S. Makkar, A. O. Aderibigbe, and K. Becker, "Comparative evaluation of non-toxic and toxic varieties of jatropha curcas for chemical composition, digestibility, protein degradability and toxic factors," Food Chemistry, vol. 62, pp. 207-15, 1998.

[20] R. Gottipati and S. Mishra, "A kinetic study on pyrolysis and combustion characteristics of oil cakes: Effect of cellulose and lignin content," Journal of Fuel Chemistry and Technology, vol. 39, pp. 265-270, 2011

[21] A. E. Pütün, B. B. Uzun, E. Apaydin, and E. Pütün, "Bio-oil from olive oil industry wastes: Pyrolysis of olive residue under different conditions," Fuel Processing Technology, vol. 87, pp. 25-32, 2005.

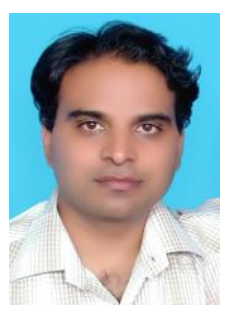

Rajeev Sharma has graduated (B.E.) in chemical engineering from Malaviya National Institute of Technology, Jaipur, Rajasthan, India and done his post graduation (M.E.) in chemical engineering from BITS Pilani, India. Presently he is pursuing Ph. D. in the field of pyrolysis of biomass waste from Chemical Engineering Department, BITSPilani, India.

He is an assistant professor of chemical engineering at Amity School of Engineering and Technology, Amity University Jaipur, Rajasthan, India. He has 5 years of teaching, research and administrative experience. His area of interest are renewable energy and environmental engineering, reaction engineering

and modeling and simulation.

Mr. Sharma is life associate member of India Institute of Chemical Engineers.

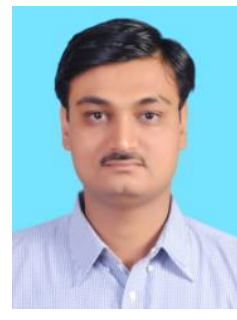

Rajasthan

His current research interests include pyrolysis, biomass gasification, modeling and simulation, computational fluid dynamics, and renewable energy sources. He has around 40 research publications including conference proceedings and book chapters to his credit which have been published over the years in various International and National Journals and Conference Proceedings.

Dr. Sheth is guiding three $\mathrm{PhD}$ students in the area of hydrogen production from biomass, biomass pyrolysis and computational fluid dynamics. Dr. Sheth has reviewed several research articles of various international journals such as biomass and bioenergy, renewable energy, renewable and sustainable energy reviews, separation science and technology, Journal of water process engineering, Journal of Petroleum technology, Journal of Engineering Tribology and African Journal of Agricultural Research.

Dr. Sheth is a life associate member of Indian Institute of chemical engineers (IIChE) and institution of engineers, India. He is also a member of AIChE since 2009. Dr. Sheth is a honorary regional secretary of the IIChE Pilani Regional Centre. He organized a workshop on analytical instruments for chemical and environmental engineers (WAICEE - 2013) during March $22-23,2013$. He was the joint organizing secretary for the 8th annual sesson of students' chemical engineering congress (SCHEMCON - 2012) during September 21-22, 2012. 